\title{
JOES $\begin{aligned} & \begin{array}{l}\text { Journal } \\ \text { of Educational } \\ \text { Study }\end{array}\end{aligned}$
}

ISSN 2798-0650

Volume 1 Issue 22021

DOI: $10.36663 /$ joes.v1i2.152

\section{The Implementation of Critical Literacy Approach towards EFL College Students}

\author{
Desak Made Yeni Wardani, Ganesha University of Education, Singaraja, Bali \\ yenidesak08@gmail.com
}

\begin{abstract}
Literacy is a crucial aspect in English education that concerns the ability to read, write, then integrate and link what they have learned to daily life. However, several researchers found that there was a lack of literacy activity in Indonesia. Literacy pedagogy was rarely seen in campus life in which it was mostly applied at primary and secondary school levels. Therefore, this study explored the implementation process of critical literacy approach in learning English for EFL college students. An action research methodology was applied in this study involving six EFL college students. The study investigated the benefits and challenges of this teaching approach. The findings indicated that critical literacy approach could improve college students' English proficiency and multiple skills, such as leadership, presentation, collaboration, self-contribution, respect, critical thinking, and expansion of multiple viewpoints through the discussion section. Improving English proficiency of college students and offering recommendations to EFL teachers for applying critical literacy approach in EFL class come as the expectation of the study.
\end{abstract}

Keywords: Critical Literacy, Action Research, EFL Students

\section{Introduction}

English has been widely spoken around the world and becomes an international language (Yuniari, 2018). It has an important role in several aspects of life such as global communication, business, diplomacy, education, and many more. In Indonesia, English has become one of required learning subjects from elementary to senior high school. Indonesian commonly start to be taught English from third grade in elementary school. Therefore, many people in Indonesia learn English as a foreign language. Two of four skills in English that should be mastered by its learners are reading and writing. Each of them has its difficulties and challenges to learn in the educational term. The ability to read and write is known as literacy.

People commonly define literacy as the ability to read and write, making people literate with various degrees of fluency. Literacy does not always mean that people can memorize of each 


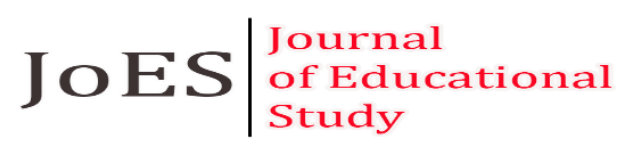

ISSN 2798-0650

Volume 1 Issue 22021

DOI: $10.36663 /$ joes.v1i2.152

information they get through the text. Instead, it refers to having the knowledge and capacity to elaborate information in different ways based on their own understanding. The center of literacy is mastering the language, which shortly focuses on how people could communicate with the language. Walker (1999) mentions that educated people in the past generation are expected to show their understanding by repeating what they have learned. However, nowadays, educated people are expected to integrate what they have learned with their own understanding then implement such information creatively to express as well as link various issues they have found with their social life.

There are many people whom can read in daily life, but still cannot write or vice versa. There are also people who both can read and write. However, de Castell, Luke \& MacLennan (1986) state that technological society has changed the meaning of literate in which it is not about the usual ability of reading and writing then make literal meaning of the text. Nowadays, it is required for people to read for social practices and more analyse to what exactly the meaning of the text from various perspectives. It supports the educational institution to teach reading with critical perspective to understand the representation and ideology in a text, subjectivity, and the author's position about a particular issue that is more precisely known as critical literacy (Luke \& Freebody, 1997).

Freire (1970) claims that critical literacy shows readers as active participants in the reading process by inviting them to think beyond what is the text looks like and manage the readers to question, examine, criticize, or dispute the power relation between readers and authors. Vasquez (2000) adds that criticizing a text in critical literacy does not always mean showing negative statement about the text, but it looks beyond the literal form of the text then analyse the issue in different ways and perspectives as well as gives suggestions of possibilities for change and improvement. There is also another supporting theory in which critical literacy helps students to see and think of the text from different perspectives and encourages critical discussions based on reflection and action delivered by Beatty (2013). Then, Luke (2007) also states that becoming critically literate allows learners to navigate many texts while questioning what the text claims and its authority in which students examine how the texts influence readers and how they can use the text to imagine other possible perspectives.

Related to the context of teaching and learning as well as improving English proficiency as a foreign language, the main focus of critical literacy approach is to make students aware of the way people value Linguistics and choices text through language text and visual reproduction as well as helping them to build their own perceptions of reality (Hatzisavvidis, Kostouli, \& Tsiplakou, 2010). Besides, each student has different background of knowledge, different experience, perspectives, and ideologies. Therefore, critical literacy could facilitate both teachers and students to cultivate respect for students' diverse views and diverse ways of thinking and 


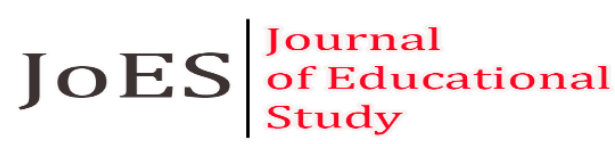

ISSN 2798-0650

Volume 1 Issue 22021

DOI: $10.36663 /$ joes.v1i2.152

interpreting, as well as to enhance students' ability to ask, examine, and explore multiple perspectives especially by using English. Critical literacy can encourage students to evaluate what have to be said and how to say it in foreign language, in this case, is English to share ideas, to state disagree, and to reconstruct textually representation in English (Gainer, 2010). It trains students to reflect on their own learning process, share opinions and collaborate with others, develop ways to deal with complex problems by using English which directly could improve their English proficiency as well. Thus, critical literacy approach can give positive impact on college students' English proficiency which is the ability of students to use and communicate in English both in spoken and written context through sharing and discussion section (Rao, 2016).

However, Ko \& Wang (2009) note that the implication and implementation of critical literacy approach in EFL class especially in the higher education level is found still limited if compared with Western Education that has applied critical literacy for years ago. The study shows that the exploration of critical literacy mostly conducted in primary or secondary level of education. Ko (2013) confirms that students in Asia still do not articulate what they are thinking, reflecting the situation of literary practice in schools. Ko also adds that the low level of critical literacy of Asian students can be seen from the EFL examination system and the practice of memorizing in EFL teaching. Meanwhile, the lack of critical literacy practice in Asia is due to a lack of understanding of the need for critical literacy in the region and a lack of knowledge as well as skills about its application (Kim, 2012). Then, Kuo (2009) argues most students are afraid to critically state their perspectives due to cultural reasons, in which expressing critical opinion to others especially to the teachers badly believed as submissive and disrespectful attitudes. In addition, EFL teaching more focuses on the use of correct English structure and form of the text rather than critically interrogating language use (Lotherington \& Jenson, 2011). Therefore, from those reasons, in this article the critical literacy approach was implemented in EFL university to investigate the benefits and the challenges of this approach towards English proficiency of EFL students in university.

Papadopoulos \& Griva (2017) define critical literacy as an educational approach that concerns to help students accepting multiple perspectives and possibilities while reading a text. Luke (2012) claims that critical term comes from Greek adjective, kriticos, which means the ability to argue and judge. Meanwhile, Paulo Freire's (1970) as cited in Luke (2012), states that the capacity to analyze, criticize then transform social, cultural, and political texts and context are called critical literacy. Lewison, Flint, and Sluys (2002) identify four basic principles of critical literacy, such as making and challenging common assumptions and values, investigating multiple perspectives, focusing on socio-political issues, and last is taking action or reflecting on reading and writing activity. On the other hand, EFL is more commonly known as English as a foreign language by which it has been classified in several countries, especially in Indonesia. Indonesian students have already become EFL students mostly since on the third grade students until on the 


\section{JOES $\begin{aligned} & \begin{array}{l}\text { Journal } \\ \text { of Educational } \\ \text { Study }\end{array}\end{aligned}$}

ISSN 2798-0650

Volume 1 Issue 22021

DOI: $10.36663 /$ joes.v1i2.152

higher education level. Iwai (2011) defines EFL students as people who learn English in nonEnglish speaking countries where it is not their first language. Indonesian, Japanese, and Chinese people can be categorized as EFL students because they learn English as a foreign language where their native language is not English.

Some researchers already conducted the similar studies as follows: the first study was conducted by Gustine (2013). The aim of the study was exploring the design and the implementation process of a critical approach and also investigating the benefits as well as challenges of the approach to teach English in an Indonesian secondary school. This study applied action research method, involving a teacher and 39 students at one school in Bandung. The results showed a benefit of using critical literacy approach in the class included students' critical engagement with text. Meanwhile the challenges of this approach implementation was represented by the unfamiliarity of the teacher and students with the approach in which English was difficult and it was more challenging to become critically literate in the foreign language. Beside of the challenges, the approach brought more positive impacts to the learning process, that the students became more active, confident, and collaborative in sharing their perspective during the discussion section. Therefore, the teacher should be encouraged to consider this approach as an alternative approach to language teaching.

Bui (2016) investigated how critical literacy was effective for high school students and the students' perceptions about the approach. The findings indicated that critical literacy pedagogy significantly improved students' English language competency and multiple skills, such as leadership, presentation, and collaboration. Moreover, the students strongly responded that critical literacy pedagogy was meaningful and applicable for their English skill improvement, sociocultural awareness, and agentive development. Thus, the study recommended for applying critical literacy pedagogy in language teaching.

The next similar study was carried out by Ko (2013) about critical literacy practices in EFL context and the English proficiency. It was aimed to explore relationship between EFL learners' critical literacy practices and the English language proficiency. It investigated four focal EFL learners' critical literacy practices in their dialogic interaction, involving 39 students' views on critical literacy learning. The findings showed the four focal students demonstrated critical literacy in varying degree, despite of their English proficiency differences. It also showed that critical consciousness of gender and class are raised through dialogic interaction. So that, a critical literacy-based class would be more acceptable to students who have high English proficiency.

Based on those previous studies, it could be assumed that critical literacy approach gave so many positives impact to the students. It could increase students' English proficiency, critical thinking through collaboration of several perspectives and views, as well as they could be more collaborative with others through sharing section.Literate students are not only about the ability to 


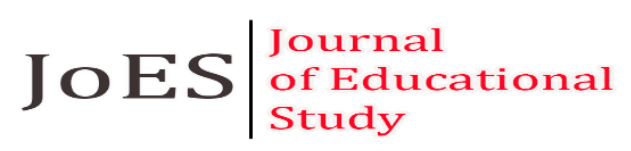

ISSN 2798-0650

Volume 1 Issue 22021

DOI: 10.36663/joes.v1i2.152

read and write a text, but it is more in how they could respond critically about what they have read or heard and link it to their daily lives. By integrating critical literacy in the EFL teaching and learning process could make the learners build their character values from being more open in everything they see or hear to be a better literate person. Therefore, this study aims to encourage Asian teacher to apply critical literacy approach in the English language class.

From the background above, the research questions of this study will be as follows:

1. How is critical literacy approach implemented in EFL classroom?

2. How does critical literacy approach in EFL class play a role in improving student's English proficiency?

\section{Method}

The action research method was applied in this study. It concerned on diagnosis, action, and reflection, which was started by identifying the problems found by the participants in the research that needed improvement. This study was designed based on the cycle of action research which was described by Kemmis and McTaggart (1990), such as plan, act, observe, and reflect. The data was collected from the interview results of six EFL college students, which were conducted online (Whatsapp chat and voice recorder feature). All data were analyzed using the critical literacy frameworks by Lewison, Flint, and Sluys (2002). Critical discourse analysis was applied in this study since it involved classroom discussion to analyze the discussion talk.

\section{Findings}

The result of this study was explained as follows: regarding to the first research question about the implementation process of critical literacy approach in EFL classroom, the researcher applied the third principles of critical literacy claimed by Lewison, Flint, and Sluys (2002), which was investigating multiple perspectives or viewpoints. It happened for about thirty minutes online discussion through Whatsapp chat and voice recorder. This principle helped students consider and accept different perspectives to understand others' experiences, feelings, and point of views. The practice of this principle occurred by engaging students in group discussion to analyse a text from different perspectives that probably could not be seen without critic. First, the researcher planned what kind of text that suitable with the principle which was ended with text about LGBT (lesbian, gay, bisexual, and transgender). Lewison, Flint, and Sluys (2002) recommended controversial and real life topics to be implemented in critical literacy classroom to provoke students' critics and perspectives easily.

In the act step, the researcher gave the topic to the six college students then asked whether it was wrong to hate people who had different sexual orientation and their opinions about LGBT. In the beginning, four of the six students thought that LGBT was something unusual or taboo and 


\section{JOES $\mid \begin{aligned} & \text { Journal } \\ & \text { of Educational } \\ & \text { Study }\end{aligned}$}

ISSN 2798-0650

Volume 1 Issue 22021

DOI: $10.36663 /$ joes.v1i2.152

seemed quite "disgusting". But then, the researcher showed a text about the pros and cons or the positive and negative sides of LGBT. Students were asked to analyse the text then started a discussion by expressing their perspectives one by one after accumulating two viewpoints of LGBT. Demonstrating the students about the importance of viewing an issue from different perspectives was the main aim in conducting this way of learning. Delgado \& Stefancic (2001) believed that considering multiple viewpoints in critical literacy education was intended to build an agenda and strategy to be a more just society and avoid underestimating human experiences.

Figure 1. The Analyzed Text

\section{Gay Marriage Should be Justifiable}

The world opposes gay marriage. That is what going on nowaday. People against the idea of having same - sex marriage. The perspective that is growing on the society is that gay marriage is a kind of taboo thing, that it is forbidden to do. But in fact, gay marriage is not that bad. Gay marriage can bring advantages, that it has to be justified by some reasons and elaborations below.

Every people have the right to have marriage, so does the gay. They have the right to have marriage with whoever the people they love. I'm elaborating and taking this point as a reason for the sake of justice. Where a good country is the country that can ensure the equality of law to all of it's citizens. Where this means that no matter who they are where they are from as long as they are the citizen of that country, they should get the same right as others. So, if heterosexual couples can have the right to have marriage, why can't homosexuals?

The other hand, the reason on why we should support gay marriage is to get acknowledgement from the government. One big question comes up. Why does acknowledgement important? It is important because it can ensure the protection for the society. The protection I meant is the marriage protection and the protection from the vandalism of the society. We will never know what is going to happen in a marriage. Without acknowledgement they will get NO protection. They can't claim if one day something bad happen in their marriage. No one will help them to solve their problem, and get the right that they think they suppose to get on a marriage. Because in fact, they don't have any rights because their marriage is illegal. Next, without government's acknowledgement, the gay marriage will have no certainity of law. And as we all know that society will not easily accept the idea of having gay marriage. Their opinion in opposing this idea will lead them to do vandalism as their reaction. And without this acknowledgement, homesexuals will get no protection. Once society do bad things to them, they have no rooms to claim. Other hand once society do vandalism, the one who will be suffered is not only the
The other reason is that, being gay is a nature. The one who are gay never choose to be so, but they just suddenly realize that they are. So it is totally unfair if we banned gay marriage by judging that it is wrong where actually that is something that come naturally ( uncontrolled ) and no one can blame it. It's like when you want to eat, it comes naturally, no one can blame you eventhough that feeling comes on the wrong time and wrong place. You just suddenly feel it. You don't try and struggle hard to be hungry. And so does the case of gay couple.
Moreover, people who oppose gay marriage used to have 3 main reasons, where I think that those reasons are weak and rebuttable. First, the religion and tradition that forbid them to have gay marriage. In fact, we are talking in general reasons, and generally not all religions oppose this idea. So it is unfair to generally said that gay marriage is wrong while actually it is not. It is also unfair, if just because of the tradition says no in te past, then now and forever we will always say no. The world is turning and so does tradition. Tradition can be changed and turned by the growth of the world, as long as it brings good impacts to society. Second reason, the perspective that is growing on the society is that gay is the reason of the spreading of HIVIAIDS. But in fact, HIV/AIDS is not a gay disease. It doesn't come only from gay couple. In the other hand, justifying gay marriage doesn't mean that we force people to to be gay. But we just justify it for the goodness of the society. The third reason is children. People think that the purpose of having a marriage is to have children. Well gay couple can't have their own child, but they can adopt children. More over, in fact, they can give the same love and attention as heterosexual couples. So by these elaborations, all of the reasons in opposing gay marriage is falling down. 


\section{JOES $\begin{aligned} & \begin{array}{l}\text { Journal } \\ \text { of Educational } \\ \text { Study }\end{array} \\ & \text { Studion }\end{aligned}$}

ISSN 2798-0650

Volume 1 Issue 22021

DOI: $10.36663 /$ joes.v1i2.152

marriage that being applied in a country will change the search, gay caring. understanding and respectful. They really respect diversity anc

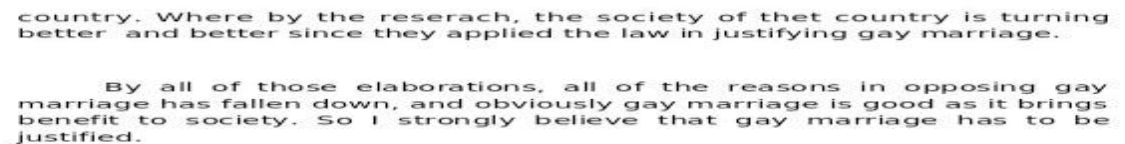

In the discussion section, the students started to show social awareness and sympathy towards people who were still not accepted in society. One of the reasons was that they had different sexual orientation or simply had different ways of showing their sexuality.

In my opinion, LGBT should not be banned, but it should not be over-indulged by those who suffer from different sexual orientations. For non-LGBT people, in my opinion, it is best just to let the LGBTS live their lives and their sexual orientation; as long as it is not disturbing, there is no need to interfere. If LGBT is against the religion you profess, then pay attention and watch yourself so that you will never become LGBT; you do not have to lecture others because if indeed they are committing sins, that's their business with God. Moreover, for the LGBT, live your life based on what you want, also pay attention to the environment where you live. If in that environment, LGBT is underestimated, so don't show too many LGBTrelated activities in public because it can endanger yourself. In essence; if you want to have fun, make sure no one is disturbed and make sure you are in a safe place. We all live side by side with different pleasures. Not all have to be the same. If you don't want to be disturbed, then don't bother, if you don't want to be agitated, then don't make other people being annoyed. That's all.

The first perspective was presented by Yuni, who thought LGBT people also have their own lives and rights, so it was not our business to insult or even judge their sexuality since the beginning of the discussion. She also stated that people should be limit themselves if they do not want to be bothered. From her answer, she showed respect for fellow human beings before and after reading the text provided.

Based on the information I have read, I believe LGBT is not a disease or a mental disorder. They are people who have deviant sexual behavior. Furthermore, I personally think I have no problem with LGBT people as long as they don't disturb me and the others. It would be good if we help them get back to normal by providing counseling. Alternatively, if indeed they feel happy with what is happening to them right now and don't want to change themselves into people who have sexual behavior like other normal people, then we don't need to worry about that. As we know, there are many cases of suicide because the LGBT feel unacceptable in society, so they feel depressed and commit to suicide. Here, we can see that they are 


\section{JOES $\mid \begin{aligned} & \text { Journal } \\ & \text { of Educational } \\ & \text { Study }\end{aligned}$}

ISSN 2798-0650

Volume 1 Issue 22021

DOI: $10.36663 /$ joes.v1i2.152

literary only human beings like us, they have the right to live happily and be accepted in society. So, it will be good if we respect each other. Don't humiliate or do things that make them feel depressed.

The own opinion of Fitri continued the sharing discussion. From the beginning, until she finished reading the text, she never showed disagreement about LGBT. On the other side, she also hoped that LGBT people could change to be normal if they wanted to, but she never said opinions against LGBT things because she had approximately the same opinion as Yuni that we could respect each other. Both of them already indicated the characteristic of critical literacy during the discussion.

I'm not really pros and cons with LGBT because every problem they have has a point of view. The pro side of me about this case is that mostly LGBT people feel that it is the best for their own sake. They also have a reason; it could be because of association or because the person has been abused or raped, which in essence, they are traumatized to the opposite sex. The cont side from me is that many people, in general, consider that LGBT is destroying their relationship (God's will). They might think that LGBT is a crime, where in fact, it is a type of mental illness that must be treated by specialist doctors. Well, the point is that as long as LGBT people don't disturb us or lead us down, it's actually fine, we shouldn't be afraid of LGBT people either. Actually, they want to be friends with the community, but because they are afraid to reveal their identity in which the community feels disgusted. The point is we must be able to respect each other.

Trio, one of LGBT person delivered the third perspective in the discussion section. He never hesitated to admit that he was bisexual because he always thought LGBT was not a crime. However, he never justified or blamed LGBT in which he just living his life with whatever he believed was right and made him comfortable. It was an appreciation for Trio to be brave in admitting his true self. It brought this to the discussion because it could encourage the others to become more open-minded to respond to LGBT from the true experience of the LGBT person.

In my view, LGBT is a mental disorder which according to LGBT experts, is caused by problems with deformities of human reproductive organs. As the information I have read said, LGBT occurs due to several factors like family factors; for example, a daughter gets harsh treatment from her father or brother, so she will tend to stay away from men because she will feel insecure or unsettled because she is always lightened by the treatment of her father and brother when she meets other men. These children are more likely to like women than men; besides that LGBT can occur due to environmental factors and also genetic factors. The fact is that the knowledge of Indonesians about LGBT itself is still limited because if Indonesians talk about LGBT, they will definitely say "Harom" even though the LGBT person is a person with mental disorders. Well, I am one of those who at first always thought that the 


\section{JOES $\mid \begin{aligned} & \text { Journal } \\ & \text { of Educational } \\ & \text { Study }\end{aligned}$}

ISSN 2798-0650

Volume 1 Issue 22021

DOI: $10.36663 /$ joes.v1i2.152

LGBT discussion was a little disgusting and annoying because there weren't many people who discussed or suffered for LGBT.

Ukik expressed another response in the discussion who was firstly thought that LGBT was taboo. Fortunately, after reading the text provided and heard the other opinions about LGBT through sharing section, he gradually reflected on how he thought in the past when he used to be a little bit judging of LGBT people. He even obtained extra information from the experts to understand more about LGBT.

The first time I heard about LGBT, I immediately link it to my religion which believes that LGBT is strictly forbidden and "haram". It is a very sinful thing. It is inappropriate because LGBT relationships are more disgusting, in my opinion. However, on the other hand, I also think that if we have LGBT friends, don't shun them but give them an approach to slowly change. My perspective is also more enlightened about how to handle when I encounter LGBT, especially after reading and exploring various points of view through discussion because I never hate the person after all, but I just do not get used to the behavior or activities of LGBT.

The next sharing idea was done by Edi, who sort of thought that LGBT was still taboo no matter what. However, he showed a good change and seemed more open and critical to LGBT things after reading the text and listening to the discussion intensively. It was shown from the statement that he did not hate the person and invited people to not spontaneously judging if they had LGBT friends. It indicated a sympathy to people who suffered for LGBT.

So, I always thought that LGBT is "haram" in my religion. In Indonesia itself, LGBT is not allowed where people are prone to spread sexual disease. Men should have relationships with women where the descendants are expected to be the successors of their future generations. If a man with man or woman with a woman what we are going to expect. However, after deepening the references related to this issue, I especially really appreciate a perspective; if I'm not mistaken, dr. Boyke once thought that LGBT people should not be shunned but should be rehabilitated with an education to make their natures return to what they should be.

The sharing section was closed by the last opinion delivered by Nias. She firmly thought and stated that LGBT was not right at first. But, she said after reading the text, several references, and different perspectives from the other students as new information, he showed a critical way of responding about LGBT. Somehow, she still did not approve of exiling LGBT people from society.

From all those interview results, the researcher could see how the students offered rich and deep perspectives about LGBT and how most of them changed their viewpoints and became more open about LGBT after reading and listening to many kinds of different perspectives. The 


\section{JOES $\mid \begin{aligned} & \text { Journal } \\ & \text { of Educational } \\ & \text { Study }\end{aligned}$}

ISSN 2798-0650

Volume 1 Issue 22021

DOI: $10.36663 /$ joes.v1i2.152

sentences "based on the information I have read" or "now I believe that..." "after deepening the references related to this issue" indicated that students already considered multiple perspectives into their actual thoughts.

Next, after practicing critical literacy approach towards college students by using considering multiple viewpoints in discussion section, this study also showed that the implementation of critical literacy approach could indirectly improve English proficiency of EFL college students. It happened due to the discussion section where students needed to read English text and try to understand the meaning, then analyse critically of what actually the text aimed to. The sharing section through voice recorder could also train the pronunciation of the students, as well as their confidence in speaking English. Next, sharing perspectives sections helped students improve their critical thinking, empathy feeling, confidence, and their speaking skill. Students are taught how to express their perspectives with appropriate and polite language so that others would not be offended. Therefore, it can be said that critical literacy approach positively impact on college students' English proficiency, such as the ability of students to use and communicate in English both in spoken and written context through sharing and discussion section.

\section{Discussions}

The purposes of the study were to know the implementation of critical literacy in EFL classroom and also to know the role of critical literacy approach in EFL class in improving students' English proficiency. The study was conducted by applying the third principles of critical literacy claimed by Lewison, Flint, and Sluys (2002), which was investigating multiple perspectives or viewpoints. There were some points that can be discussed in the discussion section, which was described as follows. According to several previous researches that conducted about the effect of using critical literacy in the EFL classroom, it showed benefits and challenges of using the approach. The benefits of using critical literacy approach towards the students' English proficiency, such as; first, the improvement of students' critical engagement with text. Next, critical literacy pedagogy significantly improved students' English language competency and multiple skills, such as leadership, presentation, and collaboration which was supported by (Rao, 2016). Moreover, Gainer (2010) added that critical literacy pedagogy was meaningful and applicable for the students' English skill improvement, socio-cultural awareness, and agentive development. Meanwhile the challenges of this approach implementation was represented by the unfamiliarity of the teacher and students with the approach in which English was difficult, so that it was more challenging to become critically literate in the foreign language. Beside of the challenges, the approach brought more positive impacts to the learning process, that the students became more active, confident, and collaborative in sharing their perspective during the discussion section. Therefore, the teacher should be encouraged to consider this approach as an alternative approach to language teaching. 


\section{JOES $\begin{aligned} & \begin{array}{l}\text { Journal } \\ \text { of Educational } \\ \text { Study }\end{array}\end{aligned}$}

ISSN 2798-0650

Volume 1 Issue 22021

DOI: $10.36663 /$ joes.v1i2.152

The findings of the study should be discussed as well. The study was conducted in EFL classroom involving six EFL college students through Whatsapp chat and voice recorder. In the beginning, the researcher planned a small online discussion and also prepared the controversial topic as what were going to be discussed. Then, the discussion section was started with simple opinion of each student about LGBT. Then, the researcher showed a text about the pros and cons or the positive and negative sides of LGBT. Students were asked to analyse the text then started a discussion by expressing their perspectives one by one after accumulating two viewpoints of LGBT. Demonstrating the students about the importance of viewing an issue from different perspectives was the main aim in conducting this way of learning. Delgado \& Stefancic (2001) believed that considering multiple viewpoints in critical literacy education was intended to build an agenda and strategy to be a more just society and avoid underestimating human experiences. As the result gained from the data collection, the students showed improvement in critical reading and thinking about the topic. By listening to various perspectives and views could make the students to be more open about in this case, LGBT. Through the critical discussion, it the students could link what they had learned to their daily lives, so that later on they could be more logic in responding LGBT. Furthermore, there were significant collaboration among the students. The students respected each other and trained to be good listeners. Therefore, it could be concluded that the usage of critical literacy approach in EFL classroom positively impacted the EFL student's English proficiency and several other skills like critical thinking, leadership, presentation, and collaboration.

\section{Implication}

There are some implications while conducting this study, such as firstly, since this study is short period research, the implementation is only conducted in one school and also only six EFL college students could participate in the research. Whereas, it can be implemented in many more schools to know deeper and wider the effects of using critical literacy approach in teaching English for EFL college students if it is done in a long time. Then, the unfamiliarity of the teacher and students with the approach in which English is difficult, so that it is more challenging to become critically literate in the foreign language. Hence, learning from the weaknesses of this study, the researcher suggests the future researchers to implement the critical literacy approach in more various class. As addition, it will also be good if the approach is used in other fields like mathematics, history, or even science. However, despite the limitation of the approach, the results show that critical literacy approach has good effects in improving EFL students' English proficiency. The approach could encourage the EFL college students to be more collaborative, critical, open minded, and wise in responding then solving the problems in their daily lives. It could also make the students to be a good listener and respect the others' opinion. Moreover, the implementation of critical literacy approach in EFL classroom could improve students' confidence 


\section{JoES $\mid \begin{aligned} & \text { Journal } \\ & \text { of Educational } \\ & \text { Study }\end{aligned}$}

ISSN 2798-0650

Volume 1 Issue 22021

DOI: $10.36663 /$ joes.v1i2.152

in speaking English during the sharing section. Therefore, the use of critical literacy approach in teaching English for EFL college students is really important to improve the students' critical thinking and English proficiency.

\section{Conclusion and Suggestions}

Critical literacy approach was still uncommon to be implemented in Asia universities, including Indonesia. Critical literacy approach not only encouraged students to think critically or analyzed the text beyond its actual meaning. But from the study, it could be concluded that critical literacy approach indeed positively impacted EFL college students because it could make the students more open-minded by considering and accepting multiple perspectives about an issue then collaborating their viewpoints with others. It was all could be accomplished by providing professional learning sessions. One of them could be in the form of discussion section by applying one of the principles of critical literacy. This study had demonstrated the implementation of critical literacy approach in the EFL classroom setting with all the participants were active during the learning process. The results of this study were strongly supported by the previous research conducted by Bui (2016), Gustine (2013), Ko (2013), Setyorini (2017), as well as Papadopoulos \& Griva (2017) who argued that critical literacy-based learning not only increases English competency, but also empowered students' meta-cognitive, meta-linguistic, and higher order of thinking skill. Hopefully, this study could motivate Indonesian English teachers to implement more a critical literacy approach, especially at the university level.

Then, after conducting the study, the researcher gives some suggestions to those who might be benefited from this research. Those suggestions can be seen as follows:

1. For English Teacher

It is suggested for English teachers to use critical literacy approach in teaching English for EFL college students because Indonesian learning system needs to be improved in order to make the students to be more critical and literate in learning the materials.

2. For Other Researchers

It is suggested to the other researchers to carry on this study since the implementation of critical literacy approach in EFL universities might need further improvement and action. This study only focuses on one subject and participated by six college students. Therefore, it is also suggested to the other researchers to continue this study by implementing bigger participation in a different subject in other schools.

\section{References}

Beatty, K. (2013). Teaching and Researching Computer-assisted Language Learning, Second Edition. JOUR. 


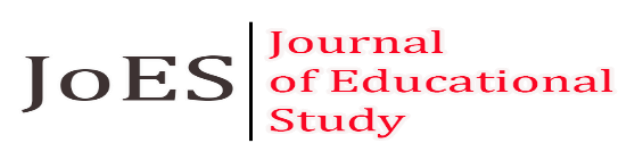

ISSN 2798-0650

Volume 1 Issue 22021

DOI: $10.36663 /$ joes.v1i2.152

Bui, T. (2016) Critical Literacy in an EFL Classroom in Vietnam: Agentive Empowerment, Ideological and Language Transformation. Vietnam. The Journal of Asia TEFL.

De Castell, S., Luke, A., \& Egan, K. (1986). Literacy, society, and schooling. Cambridge: Cambridge University Press.

Delgado, R., Stefancic, J. (2001). Critical Race Theory: An Introduction. New York: New York University Press.

Freire, P. (1970). Pedagogy of the Oppressed. (M. B. Ramos, Trans). London: Penguin Books.

Gainer, J., S. (2010). Critical Media Literacy in Middle School: Exploring the Politics of Representation. Journal of Adolescent \& Adult Literacy 53(5), 364-373.

Gustine, G., G. (2013). Designing and Implementing A Critical Literacy-based Approach in An Indonesian EFL Secondary School. International Journal of Indonesian Study, Vol. 1.

Hatzisavvidis, S., Kostouli, T., \& Tsiplakou, S. (2010). The Proposal for the Language Teaching: Critical Literacy and New Text Practices at School (in Greek). Nicosia: Pedagogical Institute.

Kemmis, S., McTaggart, R. (1990). The Action Research Planner. Victoria: Deakin University.

Kim, S., J. (2012). Critical Literacy in East Asia Literacy Classroom. Perspectives on Global Development and Technology, 11(1), pp. 131-144.

Ko, M. (2013b). A Case Study of An EFL Teacher's Critical Literacy Teaching in A Reading Class in Taiwan. Taiwan. Language Teaching Research 17, 91-108. http://dx.doi.org/10.1177/1362168812457537.

Ko, M. (2013b). A Critical Discourse Analysis of EFL Learners' Post-reading Reflection in A Critical Literacy-based Class. English Linguistics Research, 2(2). http://dx.doi.org/10.5430/elr.v2n2pl.

Ko, M., Y., \& Wang, T. (2009). Introducing Critical Literacy to EFL Teaching: Three Taiwanese College Teachers' Conceptualization. Asian EFL Journal 11(1), 174-191.

Kuo, J., M. (2009). Critical Literacy and A Picture-book-based Dialogue Activity in Taiwan. Asia Pacific Educational Review, 10(4), pp. 483-494.

Lewison, M., Flint, A., S., \& Sluys, K., V. (2002). Taking on critical Literacy: the Journey of Newcomers and Novices. Language Arts 79, 382-392.

Lotherington,, H., \& Jenson, J. (2011)Teaching Multimodal and Digital Literacy in L2 Settings: New Literacies, New Basics, New Pedagogies. York University: Cambridge University Press. Annual Review of Applied Linguistics, (31) pp. 226-246.

Luke, A. (2012). Critical Literacy: Foundational Notes. Queensland University of Technology. Theory into Practice, doi: 10.1080/00405841.2012.636324.

Luke, A. (2007). Critical Literacy Toronto. Literacy and Numeracy Secretariat. Doi: http://resources.curriculum.org/secretariat/november29.shtml.

Luke, A., Freebody, P. (1997). Shaping the Social Practices of Reading. In M. Sandy, L., Alan., F. Peter (Eds)., Handbook of Research in Second Language Teaching and Learning (Vol. 2). New York: Routledge, pp 1-15.

Papadopoulos, I., Griva, E. (2017). Promoting Critical Literacy in the EFL Context: Implementing A Project to Young Learners. Greece. International Journal of Learning, Teaching and Educational Research. 


\section{J OES $\begin{aligned} & \begin{array}{l}\text { Journal } \\ \text { of Educational } \\ \text { Study }\end{array} \\ & \text { Otudion }\end{aligned}$ \\ ISSN 2798-0650 \\ Volume 1 Issue 22021 \\ DOI: $10.36663 /$ joes.v1i2.152}

Rao, V., C., S. (2016). A Brief Study of English Language Proficiency: Employability. India. English for Specific Purposes World, ISSN 1682-257.

Setyorini, A. (2017). The Practice of Critical Literacy Teaching in EFL Classroom: A Case Study in A Reading Class in Indonesian Higher Education. Surabaya, doi: 10.5220/0007161600350040.

Vasquez, V. (2000). Our Way: Using the Everyday to Create A Critical Literacy Curriculum Primary Voices, 9(2), pp 8-13.

Walker, A., E. (1999). Characteristic of the Adult Leaner. Sage Journals, pp. 32.

Yuniari, N. M. (2018). The effect of using Powtoon audiovisual media upon the students' writing achievement of the third semester students of English education department faculty of teacher training and pedagogy Dwijendra University. Universitas Dwijendra Denpasar. 